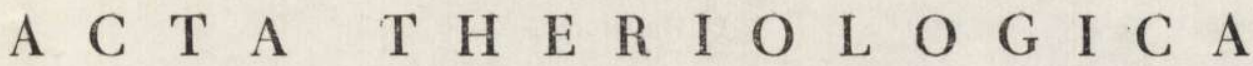

VOL. XIV, 11: 153-160.

BIAEOWIEŻA

30.VIII.1969

\author{
Lennart H A N S S O N
}

\section{Home Range, Population Structure and Density Estimates at Removal Catches with Edge Efiect*}

\author{
[With 3 Table \& 2 Figs.]
}

\begin{abstract}
By a simple formula the distance and area is calculated, from which small mamals are drawn to a trap grid with edge effect. This range estimate will increase during successive removal days but a certain plateau in this value will be equal to the mean home range radius. Structure parameters should be evaluated from animals removed until this plateau. From examinations of the catches in a Standard-Minimum grid it is suggested that there should be a shorter distance between trap stations, a longer trapping period and possibly more traps in the outer belts.
\end{abstract}

Since the establishment of the Standard-Minimum method (G r odziński, Pucek \& Ryszkowski, 1966) it has been shown that the outer belts of trap stations catch relatively more animals than the inner ones (cf. Grodziński et al. op. cit.; Ryszkowski, Andrzejewski \& Petrusewicz, 1966; Aulak, 1967, Chelkowska \& Ryszkowski, 1967). This surplus of animals at the border (»edge effect ") has been found, at least partly, to depend on animals with parts of their home ranges outside the sampling area Chelkowska \& Ryszkowski op. cit., Adamczyk \& Ryszkowski, 1968). There have been many attempts to correct for the corresponding error in density estimates (cf. A u lak, op. cit.; A da mczyk \& Ryszkowski, op. cit.; Smith, Gentry \& Golley, 1969), including Pelik a n's (1969). The last method consisted in calculating a central homogeneous area and disregarding all data obtained on trapping stations outside this area, which will sometimes mean that considerably more than half the trapped animals must be excluded from furher analysis (cf. Table 1). The present study is an attempt to develop this method in order not to loose all these data. Moreover the method presented here offers a novel way of estimating home ranges.

*) This work was supported by grants from the Swedish Natural Science Research Council. 
Dice (1938) seems to have been the first to show that the area removed at complete sampling consists of the sampling area plus a strip around it with a width of the average home range radius (Fig. 1). However, it might be assumed $a$ priori that the animals living closest to the trapping area are caught first and that thereafter animals living farther away or immigrating into the depopulated area are removed. Simultaneously there will be a decrease in the probability of capture. The symbol $r$ in Fig. 1 will therefore increase during successive trapping

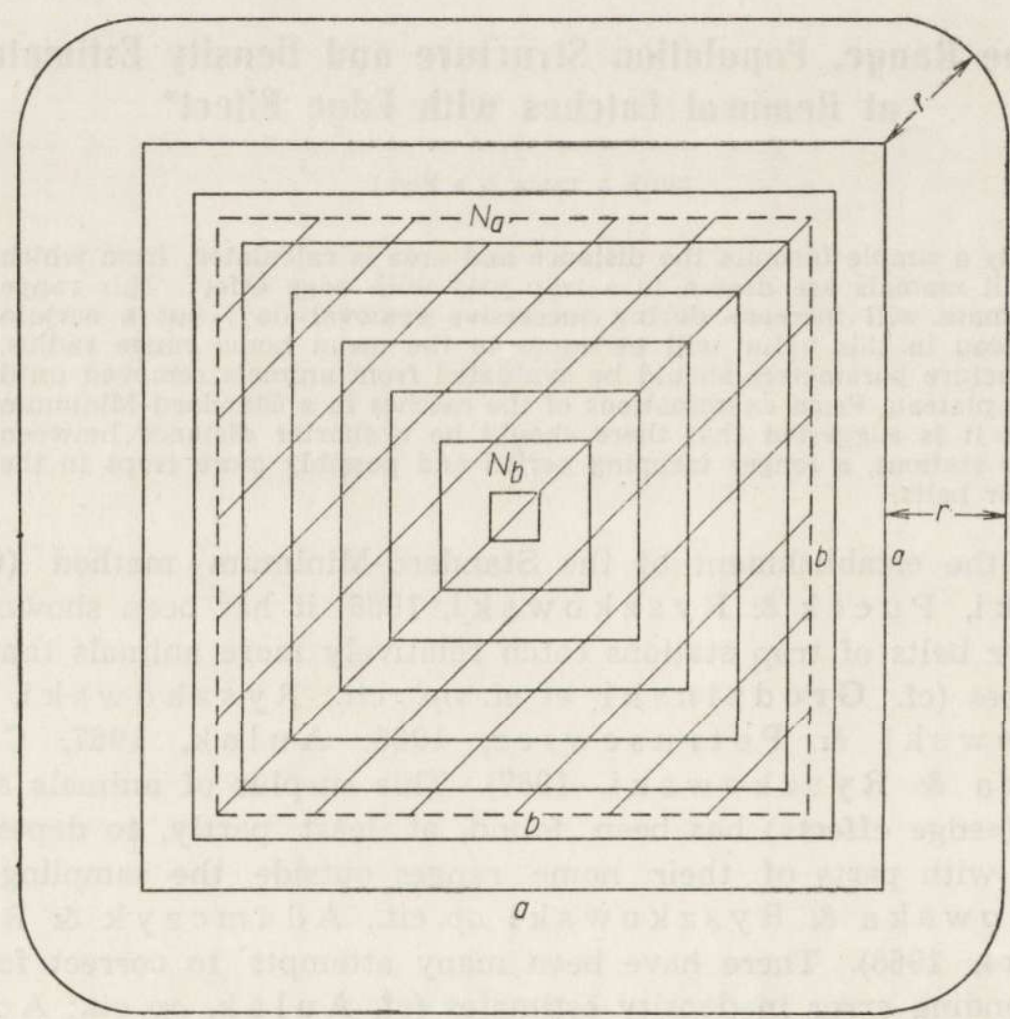

Fig. 1. Theoretical picture of the causes of the edge effect.

$a$ - side of sampling area, $b-$ side of homogeneous area, $r$ - mean range radius, hatched zone - homogeneous area, $N_{a}$ - total population on sampling area, $N_{b}$ - total population in homogeneous area.

days and might, according to M a c Luli ch (1951), be considered ssimple a mathematical average range of movement of the animals concerned during the number of days for which the traps were set«. However, if there is no pronounced immigration, there will be a plateau for some days in this value, as given by equation (1) below. Then, after this plateau, there will be an infinite increase in the $r$ value as there will not be a population vacuum for ever.

For calculating $r$ the habitat must be homogeneous and the sampling area surrounded by a large similar habitat. By homogeneity test a central homogeneous 
square of the sampling area is delimited. Assuming homogeneity in the whole habitat we obtain:

$$
N_{b} / b^{2}=N_{a} /\left(a^{2}+4 a r+\pi r^{2}\right)
$$

where

$N_{b}=$ population in the inner homogeneous square, calculated by linear regression (Hayne, 1951; Ryszkowski, 1969) or the maximum-likelihood method (Z i p pin, 1956; Janion, Ryszkowski \& Wierzbowska, 1968),

$N_{a}=$ population in the whole sampling area, calculated by the maximum-likelihood method (cf. A damczyk \& Ryszkowski, op.cit.),

$b=$ side length of inner homogeneous square, including half the distance to the next trap belt,

$a=$ side length of the sampling area (= outermost trap belt),

$r=$ average range of movement.

The animals first caught at the border may be the most active ones and may not reflect the total population structure. Therefore, population structure parameters should be evaluated from the sample removed until the days when the $r$

\section{Table 1.}

Total catches during 7 days of removal trapping on a 5.8 ha (IBP) area in a secondary spruce plantation. The catches are arranged according to consecutive belts of traps from the centre. A significant edge effect is denoted by boxed figures.

\begin{tabular}{|c|c|c|c|c|c|c|c|c|c|}
\hline \multirow{2}{*}{ Species } & \multicolumn{9}{|c|}{$\begin{array}{l}\text { Trap belt no: (in parenthesis } \\
\text { number ot trap stations). }\end{array}$} \\
\hline & & $\begin{array}{c}2 \\
(12)\end{array}$ & & & $\begin{array}{c}5 \\
(36)\end{array}$ & $\begin{array}{r}6 \\
(44)\end{array}$ & & & $\Sigma$ \\
\hline Apodemus flavicollis (M e l c h i o r, 1834) & 2 & 0 & 1 & 3 & 4 & 4 & 2 & 3 & 19 \\
\hline Apodemus sylvaticus (L in na e u s, 1758) & 1 & 1 & 1 & 10 & 9 & 7 & 20 & 32 & 81 \\
\hline Clethrionomys glareolus (S c h r e b e r, 1780) & 2 & 3 & 2 & 9 & 18 & 9 & $\mid 27$ & 50 & 120 \\
\hline Microtus agrestis ( $\mathrm{L}$ in na e us, 1761) & 4 & 8 & 13 & 18 & 15 & 28 & 32 & 39 & 157 \\
\hline Sorex araneus Linna e us, 1758 & 0 & 2 & 9 & 6 & 11 & 12 & 17 & 31 & 88 \\
\hline Sorex minutus Li n n a e us, 1766 & 1 & 2 & 3 & 2 & 1 & 2 & 3 & 6 & 20 \\
\hline Neomys fodiens (P e n n a $\mathrm{t}, 1771$ ) & 0 & 0 & 0 & 0 & 0 & 0 & 1 & 1 & 2 \\
\hline Talpa europaea Lin na e us, 1758 & 0 & 0 & 0 & 0 & 0 & 0 & 1 & 0 & 1 \\
\hline$\Sigma$ & 10 & 16 & 29 & 48 & 58 & & 103 & 142 & 468 \\
\hline
\end{tabular}

value reaches a plateau, provided there are not great differences in home ranges between different groups of the population.

This method will not of course give any other density estimates than Pelika n's (op.cit.), but it makes it possible to calculate the total area from which the collected animals are drawn.

This method was applied to a sampling for 7 days on a 5.8 ha (IBP)-grid in a secondary spruce plantation in southern Sweden in October 1968. A modified Standard-Minimum method ( $\mathrm{H}$ a n s s o n, 1969) was used, with the normal distance, $15 \mathrm{~m}$, between trap rows. 


\section{RESULTS}

The species and numbers of small mammals caught are listed in Table 1 according to the belt of trap stations. The distributions on the different belts of the 7-day catches of each species were subjected to successive homogeneity test and distributions showing $P<0.05$ were accepted as significantly heterogeneous. Such distributions were, however, only found in the two outermost belts of A. sylvaticus and C. glareolus. The material of $A$. flavicollis, S. minutus, $N$. fodiens and $T$. europaea was too small for statistical evaluations while the total distribution of captures in $M$. agrestis and $S$. araneus were homogeneous. Thus there was no point in examining the total material as there were significant differences between species.

The daily distribution of captures of A. sylvaticus and C. glareolus are shown in Table 2. The total populations in the six inner belts $\left(N_{b}\right)$ were calculated by the maximum-likelihood method and were found

Table 2.

Daily distribution of captures of two species with edge effect.

\begin{tabular}{|c|c|c|c|c|c|c|c|c|c|c|c|c|c|c|c|c|c|c|}
\hline \multirow{2}{*}{$\begin{array}{c}\text { Removal } \\
\text { day }\end{array}$} & \multicolumn{9}{|c|}{$\begin{array}{l}\text { A. sylvaticus } \\
\text { Animals in trap belt no: }\end{array}$} & \multicolumn{9}{|c|}{$\begin{array}{l}\text { C. glareolus } \\
\text { Animals in trap belt no: }\end{array}$} \\
\hline & 1 & 2 & 3 & 4 & 5 & 6 & 7 & 8 & $\Sigma$ & 1 & 2 & 3 & 4 & 5 & 6 & 7 & 8 & $\Sigma$ \\
\hline 1 & 1 & 0 & 1 & 6 & 3 & 5 & 8 & 11 & 35 & 2 & 3 & 2 & 9 & 18 & 9 & 22 & 29 & 94 \\
\hline 2 & 0 & 0 & 0 & 2 & 3 & 1 & 6 & 9 & 21 & 0 & 0 & 0 & 0 & 0 & 0 & 4 & 10 & 14 \\
\hline 3 & 0 & 0 & 0 & 2 & 1 & 0 & 0 & 5 & 8 & 0 & 0 & 0 & 0 & 0 & 0 & 0 & 4 & 4 \\
\hline 4 & 0 & 0 & 0 & 0 & 0 & 0 & 1 & 1 & 2 & 0 & 0 & 0 & 0 & 0 & 0 & 1 & 2 & 3 \\
\hline 5 & 0 & 0 & 0 & 0 & 1 & 0 & 0 & 3 & 4 & 0 & 0 & 0 & 0 & 0 & 0 & 0 & 3 & 3 \\
\hline 6 & 0 & 1 & 0 & 0 & 1 & 1 & 4 & 3 & 10 & 0 & 0 & 0 & 0 & 0 & 0 & 0 & 1 & 1 \\
\hline 7 & 0 & 0 & 0 & 0 & 0 & 0 & 1 & 0 & 1 & 0 & 0 & 0 & 0 & 0 & 0 & 0 & 1 & 1 \\
\hline
\end{tabular}

to be 30 and 43 animals respectively. The total populations of the whole grid $\left(N_{a}\right)$ were also calculated in the same way but during each trapping day beginning with the second day. From the two first days the estimate of this population of A. sylvaticus was 88 animals. Thus, according to formula (1)

$$
30 / 180^{2}=88 / 225^{2}+4 x 225 r+\pi r^{2} \text { and } r=43.6 \mathrm{~m}
$$

These range estimates are plotted in Fig. 2 against successive days of trapping. C. glareolus shows the predicted pattern of increase with a rather smooth plateau from the fifth day of removal. In A. sylvaticus however, there is at first a decrease in the $r$ estimate but a pro- 
nounced increase on the sixth removal day. For $C$. glareolus the home range radius is about $38 \mathrm{~m}$ while it is more difficult to determine the mean home range of $A$. sylvaticus.

For C. glareolus, showing no significant difference in the spatial distribution of males and females, structure parameters may be estimated on the animals collected until the fifth to seventh day. For

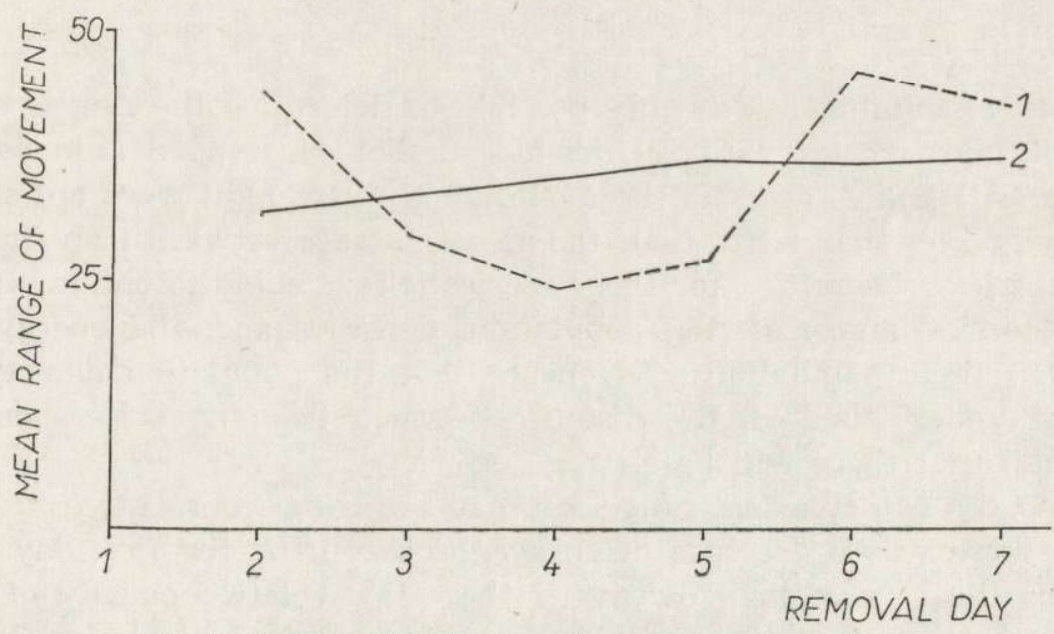

Fig. 2. Range estimates based on consecutive days.

1 - A. sylvaticus, $2-$ C. glareolus.

Table 3.

Sex and age structure in subsamples of A. sylvaticus.

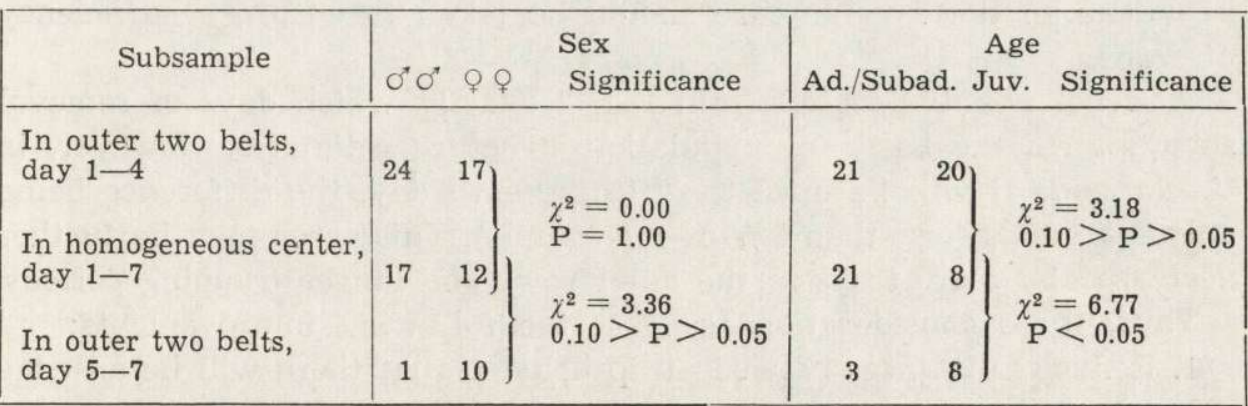

A. sylvaticus a comparison was made of two population structure parameters, sex and age, from the homogeneous inner area and the catches in the two heterogeneous outer belts during the first four respectively last three removal days (Table 3). These last catches showed clear differences and these animals may not belong to the original population but be invaders. Thus the mean home range of $A$. sylvaticus seems to 
be around $25 \mathrm{~m}$, as in Table 3 there is some evidence of an inflow of young animals already during the first days of removal. This is also indicated by the lack of a definite plateau in the $r$ value.

The actual area from which $C$. glareolus were drawn was thus 8.9 ha instead of 5.8 ha. For the original population of A. sylvaticus it seems to have been about 7.5 instead of 5.8 ha.

\section{DISCUSSION}

In this sampling it was only possible to determine the ranges of two out of four species with sufficient number of trapped animals. For $M$. agrestis and $S$. araneus the mean home range radii were not significantly greater than $9.1 \mathrm{~m}$ (half the mean distance between trap stations), perhaps less. Therefore, for these species it is possible to obtain, at best, minimum estimates of the population densities and the energy flow through their populations. To ensure that the population density will not be underestimated, the distance between trapping belts should be so small that there will be an edge effect.

Instead of increasing range estimates during consecutive trapping days, there was a decrease of A. sylvaticus during the first days. This will be the case at high density if there is a relative paucity of traps (viz. at some trap stations, cf. Andrzejewski, Bujalska, Ryszkowski \& Ustyniuk, 1966) in the outermost trap belts and this is then due to the lowered probability of capture during the first days. A. sylvaticus is highly nocturnal and will be the last taken in the traps (cf. H a n s s o n, 1967:268). In order to obtain a rapid removal and a plateau in the $r$ value care should be taken to ensure a sufficiency of traps.

It is not possible to tell from Fig. 2 exactly which days of removal should form the basis for population structure estimates. However, in C. glareolus it will be until the fifth-seventh day, the difference being only 2 animals (less than $2 \%$ of the sample). This error may be further decreased by more traps in the outer rows and longer trapping periods.

Thus, these considerations suggest the following improvements:

1. Reduced distances between trap belts so that there will be an edge effect for all species.

2. More traps per trapping station in the outer rows than in the centre, so there is an excess of traps everywhere. (This may not be necessary if correction 1 . is introduced).

3. About 10 days of removal for checking the changes in the $r$ values.

The mean home range estimate of $C$. glareolus is somewhat larger than those found by conventional methods, mainly by live-trapping 
(cf. B r ow n, 1962; 1966). They are, however, considerably smaller than those reported by Adamczyk \& Ryszkowski, op. cit.) from examination with stained bait. It was rather surprising that $A$. sylvaticus had a smaller home range than C. glareolus but there were $28 \%$ juveniles ( 8 out of 29 in the central area) of A. sylvaticus but only $3 \%$ juveniles of $C$. glareolus.

This method is based on some assumptions that have not been investigated. One is that there is no enlargement of home ranges of subordinate animals after the removal of dominants, as suggested by C a lhoun (1963), and another is that a habitat, which appears homogeneous, has a random distribution of small mammals.

Acknowledgements. I am indebted to many Polish small-mammal ecologists, especially Mr. B. Bobek and Dr. W. Grodziński, Department of Animal Genetics and Organic Evolution, Cracow and dr. L. Ry s z ow ski, Institute of Ecology, Polish Academy of Science, Warsaw, for valuable discussions on this subject. Prof. P. B rin ck, Zoological Institute, Lund, has also given great help in this study.

\section{REFERENCES}

1. Adamczyk K. \& Ryszkowski L., 1968: Estimation of the density of a rodent population using stained bait. Acta theriol., 13, 17: 295-311.

2. Andrzejewski R., Bujalska G., Ryszkowski L. \& Ustyniuk J., 1966: On a relation between the number of traps in a point of catch and trappability of small rodents. Acta theriol., 11, 13: 343-350.

3. A ulak W., 1967: Estimation of small mammal density in three forest biotopes. Ekol. pol. A, 15, 39: 755-778.

4. B r own L. E., 1962: Home range in small mammal communities. Survey Biol. Progr., 4: 131-179.

5. Brown L. E., 1966: Home range and movements of small mammals. [In: J ewe 11 P. A. \& Loizos C. (Eds.) »Play, exploration and territory in mammals«]. Symp. zool. Soc. London, 18: 111-142. Academic Press., Bristol.

6. Calhoun J. B., 1963: The social use of space. [In: M a yer W. V. \& Van Gelder R. G. (Eds.). "Physiological Mammalogy«], 1: 1-187. Academic Press. New York.

7. Chełkowska H. \& Ryszkowski L., 1967: Causes of higher abundance estimates of small rodents at the edges of sampling areas in forest ecosystems. Ekol. pol. A, 15: 737-746.

8. Dic e L., 1938: Some census methods for mammals. J. Wildl. Mgmt., 2: 119130.

9. Grodziński W., Pucek Z. \& Ryszkowski L., 1966: Estimation of rodent numbers by means of prebaiting and intensive removal. Acta theriol., 11, 10: $297-314$.

10. Hanss on L., 1967: Index line catches as a basis of population studies on small mammals. Oikos, 18, 2: 261-276.

11. Hanss on L., 1969: The Standard-Minimum method in grassland habitats. [In: Petrusewicz K., Ryszkowski R. \& Southern H. N., (Eds.) "Energy flow through small mammal populations«]. Polish Sci, Publ. - PWN, (in press). 
12. Hay ne D. W., 1949: Two methods for estimating populations from trapping records. J. Mammal., 30: 399-411.

13. Janion M., Ryszkowski L. \& Wierzbowska T., 1968: Estimate of number of rodents with variable probability of capture. Acta theriol., 13, 16: $285-294$.

14. M a c Lulich D. A., 1951: A new technique of animal census with examples. J. Mammal., 32: 318-328.

15. Pelikan J., 1969: Edge effect of sampling area. [In: Petrusewicz K., Ryszkowski L. \& Southern H. N. (Eds.) "Energy flow through small mammal populations «] Polish Sci. Publ. - PWN, (in press).

16. Ryszkowski L., 1969: Operation of Standard-Minimum method. [In: Petrusewicz K., Ryszkowski L. \& Southern H. N. (Eds.) »Energy flow through small mammal populations «] Polish Sci. Publ. - PWN, (in press).

17. Ryszkowski L., Andrzejewski R. \& Petrusewicz K., 1966: Comparison of estimates of numbers obtained by the methods of release of marked individuals and complete removal of rodents. Acta theriol., 11, 12: $329-341$.

18. Smith M., Gentry J. \& Golle y F. B., 1969: Report on the use of the Polish grid in forests of South Carolina. [In: Petrusewicz K., R yszkowski L. \& Southern H. N. (Eds.) "Energy flow through small mammal populations «] Polish Sci. Publ. - PWN, (in press).

19. $\mathrm{Z}$ ippin C., 1956: An evaluation of the removal method of estimating animal populations. Biometrics, 12: 163-189.

Received February 15, 1969.

University of Lund,

Zoological Institute,

S-22362 Lund, Sweden.

\section{Lennart HANSSON}

\section{EFEKT KRAWĘDZI A AREAE OSOBNICZY, STRUKTURA I GESTOSC POPULACJI PRZY WYEOWIE SSAKOW}

W uprawach świerkowych na terenie poludniowej Szwecji wyławiano drobne ssaki (Tabela 1) zmodyfikowaną metodą Standard-Minimum. Rozkład odłowów na poszczególnych rzędach w kolejnych 7 dniach badano testem na jednorodność. Stwierdzono istotne różnice między dwoma zewnętrznymi rzędami a centrum dla A. sylvaticus i $C$. glareolus. Rozklad wylowu $M$. agrestis i $S$. araneus był jednorodny a material z pozostałych gatunków nie byl dostatecznie liczny dla takich wyliczeń (Tabela 1). Różnice między gatunkami nie pozwalają zatem na łączne traktowanie materialu.

Ze wzoru podanego w tekście wyliczono następnie odległość z której ssaki nalowu (Ryc. 2) lecz potem ulega pewnej stabilizacji (poziom ten jest równy przeciętnemu promieniowi areału osobniczego). Parametry struktury populacji winny być oceniane dla zwierząt wyławianych do tego dnia.

Uzyskane wyniki sugerują wprowadzenie modyfikacji metody Standard-Minimum, a mianowicie: zmniejszenie odległości między rzędami pułapek; wydłużenie okresu wyłowu (do $10 \mathrm{dni}$ ); zwiększenie ilości pulapek w punkcie na rzędach zewnętrznych. 